\title{
Industrial Transformation and Economic Development Implications of Circular Economy in Kitakyushu, Japan Jialin Guan ${ }^{1, a}$, Xinmeng LV ${ }^{1, b}$, Shuai Song ${ }^{1, c}$ 1, 2, 3 Street3699, Changchun, Jilin province, China Jilin University of Finance and Economics amissguanjialin@aliyun.com, b996937917@qq.com, c327721057@qq.com
}

Keywords: Japan; Kitakyushu industrial zone; circular economy; eco-environmental policy Abstract: American economist K·Paulding first put forward the concept of "Circular Economy" in 1960s. The Kitakyushu of Japan was once a heavy industrial zone with the most acute contradiction between development and environmental problems. Since the 1960s, Japanese government started to develop circular economy in Kitakyushu and achieved unprecedented success. Its experience of transforming the old industrial bases into modern ecological community provides a good sample to countries with old industrial bases all over the world.

\section{Introduction}

Kitakyushu is located in the north of the Kyushu Japan with a total area of approximately 488 square kilometers and a total population of about 0.93 million (2016). After the Meiji Restoration, Japan's capitalism developed rapidly. With its rich coal resources, Kitakyushu soon became Japan's largest heavy industry base and steel production base. In the late 19th century and early 20th century, the coal industry in Kitakyushu entered a period of prosperity and became an important pillar of Japan's industrial development. During the two world wars, the Kitakyushu Industrial Zone was further developed to become one of the four major industrial zones in Japan based on industries of coal, steel, chemicals and shipbuilding. The development of Kitakyushu Industrial Zone derives from its special geographical location and abundant coal resources.

\section{Rise and Fall of the Kitakyushu Industrial Zone}

The Rise of the Kitakyushu Industrial Zone. Kitakyushu is the third largest island in Japan, and has 8 counties including Fukuoka, Nagasaki, Saga, Kumamoto, Oita, Miyazaki, Kagoshima, and Okinawa. Ancient Kitakyushu was the gateway to China. Many monks and scholars learned a lot of advanced technology and culture from China. In the period of Meiji Restoration, Japan implemented "Enriching Policy ", which focused on the development of heavy industry. In 1887, Japan began to build coalfield in Kitakyushu, which was rich in coal resources and its coal reserves accounted for nearly 50 percent of the national total reserves [1].

In 1901, Yahata Ironworks was established in Kitakyushu, the embryonic form of the Kitakyushu Industrial Zone. After the Sino-Japanese war in 1894, Japan plundered a lot of mineral resources from China and North Korea, developing coal-related industry such as coke, machinery, shipbuilding, metal and chemical industries. On the eve of World War I, the coal and steel production in Yahata each accounted for $60 \%$ of the total output of coal and iron in Japan [2]. After World War I, with the development of Japan's monopoly capitalism and the implementation of industrial distribution extending to the coastal areas strategy, Kitakyushu Industrial Zone further developed. After World War II, Japan implemented the industry recovery plan, and focused on restoring the national economy.

At that time, coal was still the main source of energy for industrial development, coupled with foreign exchange scarcity, Japan was unable to import cheaper energy from abroad, so the Japanese government made policies to accelerate the development of the coal industry, and provided appropriate support, Kitakyushu's coal and steel industries have ushered in a new round of rapid growth. 
The Fall of the Kitakyushu Industrial Zone. However, since the early 1950s, with the impact of the increasing depletion of the Japan coal energy and worldwide energy revolution, Kitakyushu coal and steel industry has encountered unprecedented challenges. Higher performance, lower prices oil rapidly replaced the traditional coal energy. The entire coal industry encountered crisis. The 1970s oil crisis made the prices of raw materials and fuel rose in succession in the global market, the international heavy industrial products market was basically saturated, Kitakyushu coal industry was gradually declining. In order to deal with this adverse situation, the Japanese government immediately put forward the strategic adjustment of industrial structure, promoting to develop the energy conservation industries and the high degree of processing industries. At this point, Kitakyushu's steel, aluminum, fertilizer, shipbuilding and other related industries which were incompatible with this strategy was reduced to a structure bust industries. The decline of Kitakyushu's old industrial region restricted the economic development of the whole Kitakyushu region. The structural unemployment caused by the adjustment of industrial structure was also an urgent social problem, combined with air pollution, water pollution and other environmental pollutions caused by years of acquisition of coal; the old industrial zone was in series crisis.

\section{The Development of Circular Economy in the Kitakyushu Industrial Zone}

The decline of Kitakyushu industrial zone caused several problems such as the economic downturn, the surge in unemployment and environmental pollution issues. The Japanese government implemented progressive economic transformation policies and measures, including the closure of the low efficiency of coal; placement of unemployed miners; the development of relevant laws and regulations to ensure that industrial restructuring effective; closed coal mine development of tourism; comprehensive environmental management; cultivate a new environmental type industrial park and the circular economy community. The Kitakyushu Industrial Zone achieved a smooth transition of the old industrial zone though the implementation of industrial policy, employment policy, technology policy, eco-environmental policy and law policy.

Industrial Policy of the Kitakyushu Industrial Zone. In order to achieve a smooth transition of the Kitakyushu Industrial Zone, during the years 1962-1992 Japanese government revised coal policy nine times, adjusting the coal industry structure [3]. In 1962, the Ikeda cabinet integrated consideration of the increasing decline of the coal industry, and carried out the first coal policy for Kitakyushu industrial structure adjustment. Japanese Government complied with the new trend of the world's energy revolution and proposed the closure plan of inefficient coal mines within five years. Under the compressed coal industry policy guidelines, the number of coal mines of Kitakyushu region reduced from 315 in 1961 to 37 in 1969. In order to restore Kitakyushu's economy, Japanese government absorbed a large number of unemployed labors caused by the reduction of the coal mines. A new Industrial Development Zone was established in the Kitakyushu region in the 1960s to attract new enterprises to invest and build factories stationed in the Kitakyushu region. During the years 1962-1982, the Kitakyushu region set up 76 industrial development zones. In addition, in order to further attract investment, the government has also developed a number of preferential measures to simplify procedures; exempt from local taxes and corporate tax preferential policies for enterprises who would establish new firms in the designated locations of Kitakyushu coalproducing area.

In the industrial structure adjustment, Kitakyushu paid attention to combine industrial policies with regional advantages to choose alternative industries. In the 1960s, the economic recovery period, the Japanese government has propped up the power, petroleum, chemical, steel, shipbuilding, machine tools, and household appliances as strategic leading industries according to the geographical advantages of the different regions in Kitakyushu. In the 1970s, four industries were chosen as key developing areas. First, computer, industrial robots, automobiles, IC industry, new materials such as R\&D-intensive industries; second, communications equipment, office machinery, CNC machine tools, environmental protection machinery, and large construction machinery equipment industry; third, high-end clothing, high-end furniture and housing supplies on behalf of 
the fashion industry; fourth, information services, software, engineering systems, consulting services were chosen as the representative of the knowledge industry.

Employment Policy of the Kitakyushu Industrial Zone. In the process of economic recovery and industrial transformation, old resource depletion industrial zone will inevitably face the urgent problem of unemployment. The first step in the transformation of old industrial base in Kitakyushu was to shut down the region of low efficiency coal mines, which led to hundreds of thousands of unemployed workers. In order to solve this thorny issue, the Japanese government has taken a series of measures to assist unemployment workers, including a career transition, vocational training and reemployment assistance to help unemployed workers; issue for unemployed miners at a reasonable adjustment leave and pension payments; Employ coal unemployed workers of local enterprises to implement the preferential lending policies, $2 / 5$ of the funds needed will be provided with lowinterest loans; settle Development Zone to invest new businesses. These practices ensure the mining area unemployed workers re-employed successfully, avoiding the further economic depression and social chaos in Kitakyushu.

Technology Policy of the Kitakyushu Industrial Zone. When conducting industrial transformation of industrial base in Kitakyushu, the Japanese government focused on the combination of industrial policy with advanced technology. In the 1950s, the advanced technology imported from abroad was more than 26000 . The application of these technologies has played a positive role in the delay of the decline of old industrial bases. Meanwhile, Japan also paid special attention to the digestion and absorption of sophisticated technology and further imitates the innovation. Japan has the world's largest scientific research personnel, and funds for imitative innovation which is several times of the introduction of technology funds, but the innovative capacity often several times higher than the imported technologies.

The eco-environmental policy of the Kitakyushu industrial zone. The developing mode of Kitakyushu centered on heavy and chemical industries caused serious ecological and environmental hazards. Due to long-term environmental pollution, from the late 1950s to the 1970s, Japan emerged Four Public Nuisance Diseases which shocked the world. Kitakyushu accounted for two of the Four Public Nuisance Diseases, which seriously endangered the safety of the public in Japan [4]. The Japanese Government attached great importance to the Four Public Nuisance Diseases. From the late 1950s, the Japanese Government launched a series of measures in the renovation of the Four Public Nuisance Diseases. In 1971, Japan also established the Department of Environmental Protection in order to ensure the implementation of eco-environmental policy. Japan's public nuisance problem has been significantly improved in the late 1970s, which laid the foundation of further ecological and environmental management.

In Kitakyushu, the broader impacts of pollutions are air pollution and water pollution. Air pollution was caused by years of coal mining. The coal dust had a serious impact on the quality of living and safety of the inhabitants of the region. Water pollution problem mainly refers to water pollution in Causeway Bay, northern Kitakyushu. With the sewage discharged by the Yalata Iron Works in the operations result in less and less dissolved oxygen content within the Causeway Bay, and finally approaching zero, leading to all deaths of marine life in the Bay. Causeway Bay became worthy of the name "Dead Sea". From 1970s to 1980s, according to more and more serious garbage, sewage, air and noise pollutions, the Japanese government introduced a "long-term vision of environmental preservation measures" which aimed to address both the prevention of public nuisance and the protection of the ecological environment [5]. And now, three water areas, as well as other two rivers, have markedly improved. Meanwhile, the flow and the gulf have been restored its natural function [6].

In the 1990s, under the background of global concern on environmental issues, Kitakyushu started the "Eco-Industrial Park Project" aimed at the construction of resource recycling-type city, which was supported by the Japanese government. The former most polluted Kitakyushu City was among the first "eco-industrial park project" cities [7]. Japan's eco-industrial park involves three main types, including the industrial park for the recycling of waste, the industrial park for the disposal of 
the waste, industrial park for the creation of the environmental community. It is worth mentioning that, a number of universities and academic research institutions were produced in the vicinity of the environmentally friendly industrial park, which contributed greatly to the development of circular economy. Kitakyushu City has now become a model for the world's "Ecological City" and "Recycling City".

\section{Conclusions}

Circular economy is to rely on the cycle of ecological resources to economic development that goes beyond the traditional economic development model at the expense of resource [8]. The successful industrial transformation of Kitakyushu derives from the implement of circular economy. Its successful experience of transforming the old industrial bases provides a good sample to countries in the world, especially in old industrial bases. Kitakyushu' circular economy mode involves many specific policies. Countries all over the world especially the old industrial areas can develop circular economy from adjusting its industrial policy, employment policy, technology policy and ecoenvironmental policy.

\section{Acknowledgments}

This work was financially supported by Jilin Provincial Social Science Fund (2015BS42), Social Science Research Fund of Jilin Provincial Education Department "The Twelfth Five-Year Plan" (2014 No.137)and Science Research Project of Jilin University of Finance and Economics (2016Z02).

\section{References}

[1] J.P.Sun: The Revival of kyushu and Industrial Policy in Japan. Contemporary Economy of Japan. Vol.1 (1999)

[2] Q.Zh.Sheng, P.S. Sun, X.N.Zh: International experience of Resource-based Industrial Zone and the Northeast Revitalization Countermeasures. Technology Management Research.Vol.10 (2006)

[3] X.Y.Zhao,R.G.Zhang: Study on the Principle of Selection of the Industry in Resource Depletion Region. Contemporary Economic Research. Vol.7 (2009)

[4] W.M.Li, Y.P.Chen, W.G.Li: A Comparative Study on Urban Environment Policy Development. Vol.7 (2001)

[5] L.Y. Dong: The Theory and Practice of Constructing Low-carbon Green City. Fujian Tribune. Vol.3 (2012)

[6] Eishichi Ishii: Building Eco-Cities tow ards Zero Waste Community, United Nations Centre for Regional Development. http://www.uncrd.or.jp/env/ipla/doc/130112 Presentation4.pdf, p17-18 (2013)

[7] Kishimoto,X.Peng: The evolvement of Kitakyushu City's environmental policies .Contemporary Economic Science. Vol.11 (2011)

[8] P.C.Xiao. The Experiences and Implications of Kitakyushu's Circular Economy. Journal of Science and Technology. Vol.2 (2010) 